\title{
Protein Fractionation of Green Leaves as an Underutilized Food Source-Protein Yield and the Effect of Process Parameters
}

\author{
Anna-Lovisa Nynäs *D, William R. Newson and Eva Johansson $\mathbb{D}$ \\ Department of Plant Breeding, Swedish University of Agricultural Sciences, P.O. Box 190, SE-23422 Lomma, \\ Sweden; bill.newson@slu.se (W.R.N.); eva.johansson@slu.se (E.J.) \\ * Correspondence: anna-lovisa.nynas@slu.se
}

check for

updates

Citation: Nynäs, A.-L.; Newson, W.R.; Johansson, E. Protein

Fractionation of Green Leaves as an Underutilized Food Source-Protein Yield and the Effect of Process Parameters. Foods 2021, 10, 2533. https://doi.org/10.3390/ foods10112533

\section{Academic Editor:}

Anne-Sylvie Fabiano-Tixier

Received: 18 September 2021

Accepted: 17 October 2021

Published: 21 October 2021

Publisher's Note: MDPI stays neutral with regard to jurisdictional claims in published maps and institutional affiliations.

Copyright: (c) 2021 by the authors. Licensee MDPI, Basel, Switzerland. This article is an open access article distributed under the terms and conditions of the Creative Commons Attribution (CC BY) license (https:// creativecommons.org/licenses/by/ $4.0 /)$

\begin{abstract}
Green biomass has potential as a sustainable protein source for human consumption, due to its abundance and favorable properties of its main protein, RuBisCO. Here, protein fractionation outcomes of green leafy biomass from nine crops were evaluated using a standard protocol with three major steps: juicing, thermal precipitation, and acid precipitation. Successful protein fractionation, with a freeze-dried, resolubilized white protein isolate containing $\mathrm{RuBisCO}$ as the final fraction, was achieved for seven of the crops, although the amount and quality of the resulting fractions differed considerably between crops. Biomass structure was negatively correlated with successful fractionation of proteins from biomass to green juice. The proteins in carrot and cabbage leaves were strongly associated with particles in the green juice, resulting in unsuccessful fractionation. Differences in thermal stability were correlated with relatedness of the biomass types, e.g., Beta vulgaris varieties showed similar performance in thermal precipitation. The optimal $\mathrm{pH}$ values identified for acid precipitation of soluble leaf proteins were lower than the theoretical value for RuBisCO for all biomass types, but with clear differences between biomass types. These findings reveal the challenges in using one standard fractionation protocol for production of food proteins from all types of green biomass and indicate that a general fractionation procedure where parameters are easily adjusted based on biomass type should instead be developed.
\end{abstract}

Keywords: leaf protein extraction; RuBisCO; green biorefinery; leaf protein concentrate; white protein precipitation; thermal protein precipitation

\section{Introduction}

In Europe and beyond, consumer preferences are shifting to increased consumption of plant-based instead of animal-based protein [1,2]. This shift has resulted in a multitude of novel products appearing on supermarket shelves. However, these novel food products, like protein-based animal feed products currently in use, are largely based on soy protein [3], the majority of which is grown in America and Asia [4]. Thus, replacement of soy with locally produced plant protein would contribute to food independence for the country of production, while a reduction in transportation could lead to increased sustainability [5]. Valorization of green leaves by protein extraction has been a concept since the 1940s [6], but has gained increasing attention in recent decades as an additional plant protein source for food and feed $[7,8]$. Green leaves are a major source of biomass worldwide and also one of the largest side-streams from modern agricultural and horticultural production. For example, only $20-50 \%$ of total plant biomass of broccoli is currently harvested and used for food [9], and similar percentages can be expected for crops such as carrot, beetroot, sugarbeet, and cabbage. Increased and diversified use of the residual side-streams would increase sustainability and profitability in crop production.

Fresh green leaves consist of 1.6-8.2\% protein, with large variation between species [8]. The major protein in all green leaves is the enzyme ribulose-1,5-bisphosphate carboxylase/oxygenase (RuBisCO), considered the most abundant protein in the world [10]. RuBisCO catalyzes uptake of $\mathrm{CO}_{2}$ during photosynthesis and is therefore present in high 
amounts in all photosynthetic organisms. RuBisCO is an interesting target protein as a source for novel protein-rich foods, as it has a highly desirable amino acid composition for human consumption and functional properties resembling those of soy and whey protein [11-13].

Protein fractionation can be utilized to create value-added products from leaf proteins, resulting in (i) a green protein fraction, mainly consisting of membrane-bound proteins and chlorophyll-related proteins, and (ii) a "non-green" protein fraction of water-soluble proteins, mainly RuBisCO [14]. This fraction is commonly referred to as "white protein", a convention followed in this paper. The white protein fraction has been shown to be beneficial for humans, with high levels of essential amino acids $[13,15,16]$. It has also been shown to have functional properties useful in food applications, e.g., foaming, emulsification, and gelation [11-13,16-18].

Most published studies on protein fractionation from green biomass for food applications have applied a relatively gentle extraction process, to maintain the desirable functional properties of the proteins [18]. This process generally consists of three main steps (Figure 1): (i) pressing liquid from fresh or frozen green leaves to obtain a green juice (GJ); (ii) separating the green and white protein fractions by exploiting differences in thermal sensitivity of the proteins, to create white juice (WJ) and a green protein fraction [11,13,18-21]; and (iii) concentrating the white protein fraction in the WJ further, by heating at $80{ }^{\circ} \mathrm{C}$ [19], acid precipitation at $\mathrm{pH}$ between 3.5 and 4.5 [13,16,22-24], chromatography [20], or filtration $[11,17]$.

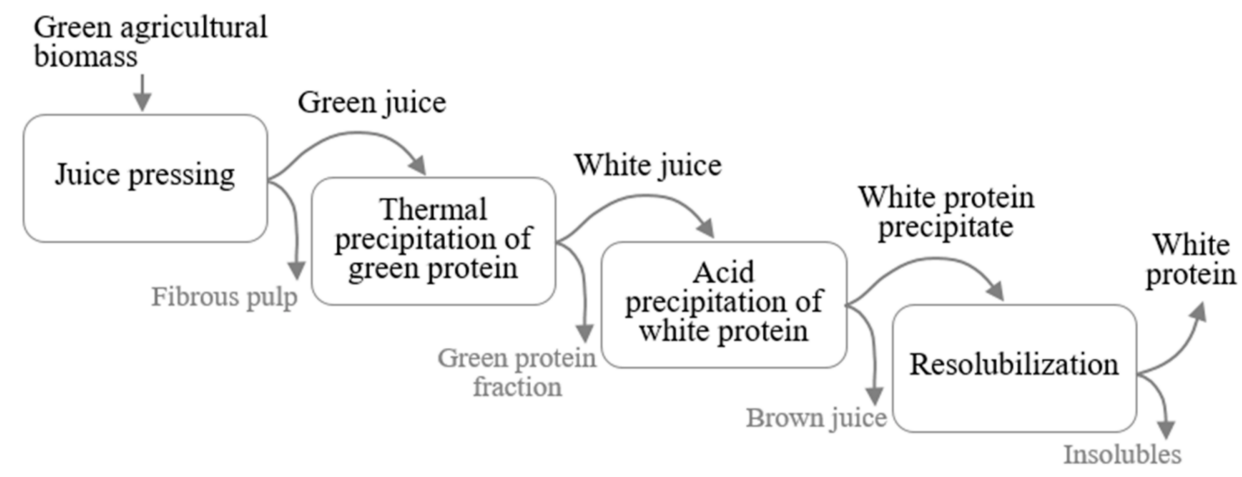

Figure 1. Main steps in a general process for producing white protein isolate from green agricultural biomass.

Industrial-scale protein fractionation of green leaves for food would require a yearround process where a range of different biomass types are used in a similar methodological system. In a Nordic context, biomass availability will clearly vary between seasons and a biorefinery would benefit from having multiple raw materials available. However, previous studies have mainly focused on green biomass of three crops (lucerne, sugarbeet, and spinach) for protein fractionation [11,13,15-18,21,23-32], with only a few studies focusing on other biomass sources (e.g., beetroot, broccoli, cauliflower, or cabbage leaves [33]). Thus, there is limited information available on how different biomass sources perform as raw material in protein extraction and how the extraction process may need to be adapted for individual sources.

The aim of the present study was to evaluate the role of green biomass source in protein fractionation and to characterize the background and underlying reasons for any differences between biomass types. In characterization, the emphasis was on protein precipitation temperatures suitable $\mathrm{pH}$ for white protein precipitation and on the flow of water, dry matter, and nitrogen through the extraction process. An overarching goal was to establish a basis for industrial use of green agricultural waste/side-streams for protein valorization into food ingredients, additives, and products. The starting hypothesis was that any green leafy biomass can be used as raw material in a general protein extraction process. 


\section{Materials and Methods}

\subsection{Collection of Biomass}

To evaluate similarities and differences between a wide array of green biomass sources of possible use in a Nordic set-up for protein fractionation, nine different crops were selected (Table 1). Fresh leafy harvest residues from broccoli, cabbage, kale, carrot, beetroot, and sugarbeet were collected from fields in southern Sweden at the time of harvest. The mangold residues were over-mature and not suitable as a food ingredient, mainly due to cosmetic reasons, but did have a value as a green biomass. Lucerne (first cut) was collected from a field on campus in Alnarp, Sweden. Fresh baby spinach was included in the study as a model crop, as it has previously been shown to perform well in a protein extraction process, it was purchased from a supermarket. After collection, all biomass was rinsed with tapwater, frozen, and stored at $-20{ }^{\circ} \mathrm{C}$ until processing. Samples for dry matter and nitrogen determination were collected prior to freezing, the details are described in Section 2.4. Further processing was done following the procedure described in Section 2.2, based on process parameters developed in Section 2.3.

Table 1. The nine types of agricultural green biomass evaluated in this study and their nitrogen (N) content on a dry matter (DM) basis.

\begin{tabular}{|c|c|c|c|c|}
\hline \multicolumn{2}{|c|}{ Biomass Source } & \multirow{2}{*}{$\begin{array}{c}\text { Collection Date } \\
2 \text { October } 2017\end{array}$} & \multirow{2}{*}{$\begin{array}{l}\% \mathbf{N} \\
3.2\end{array}$} & \multirow{2}{*}{$\begin{array}{c}\text { \%DM } \\
13.3\end{array}$} \\
\hline Broccoli * & Brassica oleracea, var. italica & & & \\
\hline Cabbage * & Brassica oleracea, var. capitata & 30 August 2017 & 2.1 & 11.0 \\
\hline Kale * & Brassica oleracea, var. sabellica & 23 October 2017 & 3.0 & 13.3 \\
\hline Mangold & Beta vulgaris, subsp. vulgaris, var. cicla & 30 August 2017 & 2.1 & 8.4 \\
\hline Beetroot* & Beta vulgaris, subsp. vulgaris, var. Red hawk & 13 September 2017 & 3.2 & 9.9 \\
\hline Sugarbeet * & Beta vulgaris, subsp. vulgaris, var. Lombok & 12 October 2018 & 3.0 & 13.0 \\
\hline Carrot* & Daucus carota subsp. sativus & 28 June 2018 & 2.1 & 17.7 \\
\hline Lucerne & Medicago sativa & 25 May 2018 & 2.8 & 20.9 \\
\hline Spinach & Spinacia oleracea & Retail ** & 4.8 & 10.6 \\
\hline
\end{tabular}

\subsection{Protein Fractionation from Green Leaves}

To enable direct comparisons of different green leaf sources during protein fractionation, the same protein fractionation procedure was applied for all crops. The methodology selected was mainly based on literature data $[18,24,28,31]$, although with some modifications. In principle, the fractionation procedure comprised three steps; screw pressing, thermal precipitation, and acid precipitation (see Sections 2.2.1-2.2.3). To investigate the background and reasons for differences in biomass behavior during protein fractionation, additional steps were included (see Section 2.3). A Sankey chart of the full process is shown in Figure 2.

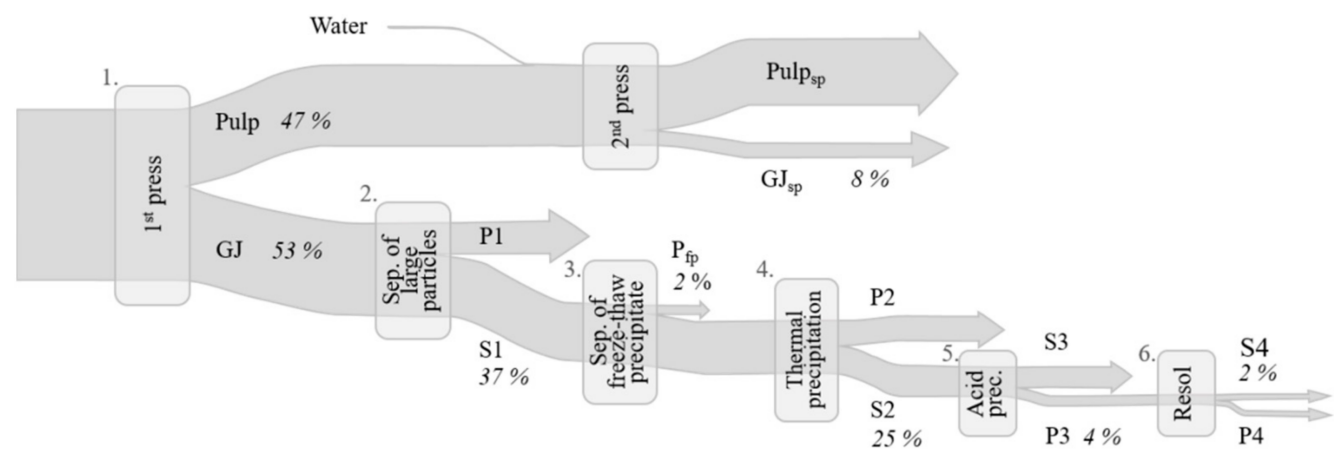

Figure 2. Sankey chart of the full protein extraction process, including all additional steps, with values for mangold as an example. Percentages shown indicate nitrogen flow through the process steps 1-6 (\% of initial biomass nitrogen). GJ: green juice, S: supernatant, P: pellet, sp: second press, fp: freeze precipitate. 


\subsubsection{Juice Pressing}

Frozen leaves of the selected crops were thawed and divided into three $300 \mathrm{~g}$ portions, representing process triplicates. Thawed, but still cold, leaves were juiced in a twin-screw press (Angelia 5500, Angel Co., Ltd., Busan Korea), and the green juice (GJ) obtained was centrifuged $\left(11,800 \mathrm{RCF}, 10 \mathrm{~min}, 4^{\circ} \mathrm{C}\right)$, producing a particle-free supernatant (S1) containing water-soluble proteins, and a pellet with particles (P1). The extruded fibrous pulp was mixed with MilliQ water corresponding to $50 \%$ (or $100 \%$ for carrot) of its mass after sampling and re-fed to the juicer. As in the first juicing, the second press resulted in a green juice $(\mathrm{GJ} s \mathrm{sp})$, which was collected and centrifuged into an $\mathrm{S} 1_{\mathrm{sp}}$ and $\mathrm{P} 1_{\mathrm{sp}}$ fraction. Portions of all samples were freeze-dried for dry matter determination and analysis of nitrogen content. The additional $\mathrm{S} 1$ juices were stored at $-20{ }^{\circ} \mathrm{C}$ until further processing.

\subsubsection{Thermal Precipitation}

Subsamples of thawed $\mathrm{S} 1$ juice $(40 \mathrm{~mL})$ from each crop and process replicate were transferred to triplicate $50 \mathrm{~mL}$ conical tubes and centrifuged (3200 RCF, $10 \mathrm{~min}, 4^{\circ} \mathrm{C}$ ) to remove particles resulting from protein precipitation during freezing $\left(\mathrm{P}_{\mathrm{fp}}\right)$. The supernatant in each tube was transferred to a new tube and thermally treated in a water bath at $55^{\circ} \mathrm{C}$ for $25 \mathrm{~min}$. The thermally treated samples were immediately cooled on ice and centrifuged (3200 RCF, $10 \mathrm{~min}, 4^{\circ} \mathrm{C}$ ), resulting in a supernatant (S2) containing the white protein fraction, and a pellet (P2) containing the green protein fraction. The supernatants were frozen and stored at $-20^{\circ} \mathrm{C}$ until further processing. Aliquots of the S2 supernatant and the pellets $\left(\mathrm{P}_{\mathrm{fp}}\right.$ and $\left.\mathrm{P} 2\right)$ were freeze-dried and analyzed for dry matter and nitrogen content, while the remaining $\mathrm{S} 2$ supernatant was retained for further processing.

\subsubsection{Acid Precipitation and Resolubilization of the White Protein Fraction}

Part of the S2 fraction of each crop and their process replicates were $\mathrm{pH}$-adjusted to 4.5 by drop-wise addition of $1 \mathrm{M} \mathrm{HCl}$, and the solution was divided into (A) a sample with total volume $1.5 \mathrm{~mL}$ for monitoring precipitation yield, and (B) a sample with volume $8.0 \mathrm{~mL}$ intended for resolubilization of the precipitated white protein (see Figure 2). The precipitated particles in both sample sets were separated by centrifugation (1150 RCF, $10 \mathrm{~min}, 4^{\circ} \mathrm{C}$ ), and the supernatant (S3) was separated from the pellet (P3). The S3 and P3 from sample A were weighed and frozen. The P3 from sample B was dispersed in $1 \mathrm{~mL}$ MilliQ water and the $\mathrm{pH}$ of the solution was adjusted to 7 through drop-wise addition of 0.1 $\mathrm{M} \mathrm{NaOH}$. Thereafter the sample was stirred at room temperature for $30 \mathrm{~min}$, followed by gentle centrifugation $\left(260 \mathrm{RCF}, 5 \mathrm{~min}, 4^{\circ} \mathrm{C}\right.$ ) to remove insoluble particles. The supernatant (S4) was poured off and the pellet (P4) was washed by addition of $1 \mathrm{~mL}$ MilliQ water, mixing, and another centrifugation step. The supernatant was then pooled with the first S4. To assess unintended protein precipitation due to freezing, a $1.5 \mathrm{~mL}$ sample of $\mathrm{S} 2$ from each crop and process replicate was treated following the same procedure as described for sample A, but without $\mathrm{pH}$ adjustment. The supernatant and pellet from this test are referred to as $\mathrm{S}_{\mathrm{fp} 2}$ and $\mathrm{P}_{\mathrm{fp} 2}$. All samples produced ( $\mathrm{S} 3$ and $\mathrm{P} 3$ from sample $\mathrm{A}, \mathrm{S}_{\mathrm{fp} 2}, \mathrm{P}_{\mathrm{fp} 2}, \mathrm{~S} 4$, and $\mathrm{P} 4$ ) were freeze-dried and the dry matter and nitrogen content were determined.

\subsection{Thermal and Acid Precipitation Tests to Determine Differences between Biomass Sources \\ 2.3.1. Thermal Precipitation}

The $\mathrm{S} 1$ fraction from the different crops and their processing replicates were thawed on ice and $100 \mu \mathrm{L}$ aliquots were transferred to $300 \mu \mathrm{L}$ micro-Eppendorf tubes. For each crop and processing replicate, three tubes per temperature were placed in a water bath at $40,45,50,55,60,65,70$, or $80^{\circ} \mathrm{C}$ for $10 \mathrm{~min}$, and placed on ice immediately afterwards. A reference sample corresponding to $0{ }^{\circ} \mathrm{C}$ was left on ice. The samples were centrifuged (1900 RCF, $10 \mathrm{~min}, 4^{\circ} \mathrm{C}$ ) to separate the precipitated protein from the soluble proteins. The protein concentration in the supernatant of each sample was analyzed in triplicate using a bicinchoninic acid protein assay kit (Pierce BCA protein assay, Thermo Scientific, 
USA) in 96-well format according to the manufacturer's instructions, using a Multiskan GO spectrophotometer (ThermoFisher Scientific, Vantaa, Finland).

\subsubsection{Acid Precipitation}

Part of the S2 fraction was filtered through a $0.45 \mu \mathrm{m}$ syringe filter to remove particles. The filtrate was diluted in MilliQ water to reach a protein concentration of around $1 \mathrm{mg} / \mathrm{mL}\left(\mathrm{W}_{\text {prot }} / \mathrm{V}\right)$, transferred to a disposable capillary zeta cell (Malvern Instruments, Malvern, UK), and analyzed with a Zetasizer nano ZS (Malvern Instruments, Malvern, UK) coupled with an autotitration unit (MPT-2, Malvern). The $\mathrm{pH}$ of the solution was changed in steps of 0.5 units using 0.1 and $0.01 \mathrm{M} \mathrm{HCl}$, and particle size and their zeta potential (ZP) were measured at each step. Duplicate measurements were made for two process replicates, and at each $\mathrm{pH}$ value triplicate particle size and $\mathrm{ZP}$ measurements were averaged.

\subsubsection{SDS-PAGE Analysis}

Sodium dodecyl sulfate-polyacrylamide gel electrophoresis (SDS-PAGE) analysis was performed using an analysis kit with pre-cast gradient mini-gels (Invitrogen Novex Bolt, 4-12\%, Bis-Tris Plus, Thermo Fisher Scientific, Waltham, MA, USA), and a protein ladder (Invitrogen SeeBlue ${ }^{\circledR}$ ). A voltage of $145 \mathrm{~V}$ was applied during $35 \mathrm{~min}$ for separation. The protein bands were stained for $15 \mathrm{~min}$ (GelCode ${ }^{\mathrm{TM}}$ Blue Safe protein stain, Thermo Scientific, USA), and the gels were washed overnight. For SDS-PAGE analysis of freeze-dried protein concentrates, the material was dissolved in MilliQ water to reach a concentration of $4 \mathrm{mg}$ dry material $/ \mathrm{mL}$ and the samples were mixed at room temperature for $10 \mathrm{~min}$ before analysis. In SDS-PAGE analysis, the RuBisCO subunits are found at $\sim 55 \mathrm{kDa}$ and $\sim 14 \mathrm{kDa}[10]$.

\subsection{Dry Matter and Nitrogen Determinations}

Fresh biomass samples of 3 or $5 \mathrm{~g}$ were oven-dried in duplicate or triplicate at 110 or $130{ }^{\circ} \mathrm{C}$. All other samples were freeze-dried. All samples were weighed before and after drying, and the dry matter content was calculated. Nitrogen $(\mathrm{N})$ determination was carried out on dried samples through applying the Dumas method on a Flash 2000 NC Analyzer (Thermo Fisher Scientific, Waltham, MA, USA) in duplicate. In this study the N content is presented, rather than protein content, since the conversion factor ( $\mathrm{N}$ content to protein content) was not known for the materials used.

\subsection{Yield Calculations}

Process yield of total $\mathrm{N}$ and of total dry and wet matter, for each specific process step and for the full process, was calculated as:

$$
\text { Yield }_{X, F}=\frac{X_{F, \text { out }}}{X_{F, \text { in }}}
$$

where $\mathrm{X}$ is total $\mathrm{N}$, total dry matter, or total wet matter, and $\mathrm{F}$ is the process step, or steps, for which the yield is calculated. The yields were calculated for each process replicate separately and the mean values \pm standard deviation are presented, with the numbers of replicates as stated in the method descriptions above.

\subsection{Calculation of Theoretical $p I$}

The theoretical isoelectric point (pI) for spinach RuBisCO was determined using the online pI calculation tool ProtParam on the Expasy server (web.expasy.org/cgi-bin/ protparam/protparam, accession data 5 June 2020) [34]. The amino acid sequences were taken from the UniProt database under the entries P00870 (small subunit) and P00875 (large subunit) (www.uniprot.org, accession date 5 June 2020). 


\subsection{Statistical Evaluation}

Flows of N, dry matter, and total mass through the process for the different crops were compared using general linear model analysis of variance (ANOVA) with KenwardRoger's method and a significance level of $p<0.05$, followed by Tukey post-hoc test. All statistical analyses were performed in RStudio version 1.4.1106 [35], using the function packages lme4, emmeans, lmerTest, multcomp, and multcompView. The Kenward-Roger's method was chosen due to the complex correlation structures of the data [36].

\section{Results and Discussion}

\subsection{Effect of Biomass Source on Protein Fractionation}

Protein fractionation with the selected method was successful for seven out of nine of the green biomass sources evaluated, as demonstrated by the $\mathrm{N}$ yield from the original biomass (BM) to re-dissolved white protein (S4) (Table 2a, Supplementary Figure S2). For carrot and cabbage protein fractionation was not successful, as shown by the low $\mathrm{N}$ yield and lack of RuBisCO in $\mathrm{S} 4$ from these crops (Figure 3). Thus, the origin of green leafy biomass had a large impact on the protein fractionation outcome, contradicting the hypothesis that any green leafy biomass can be used as raw material in a general protein extraction process. Other studies have achieved successful protein extraction from, e.g., cabbage, by applying different extraction methods [33].

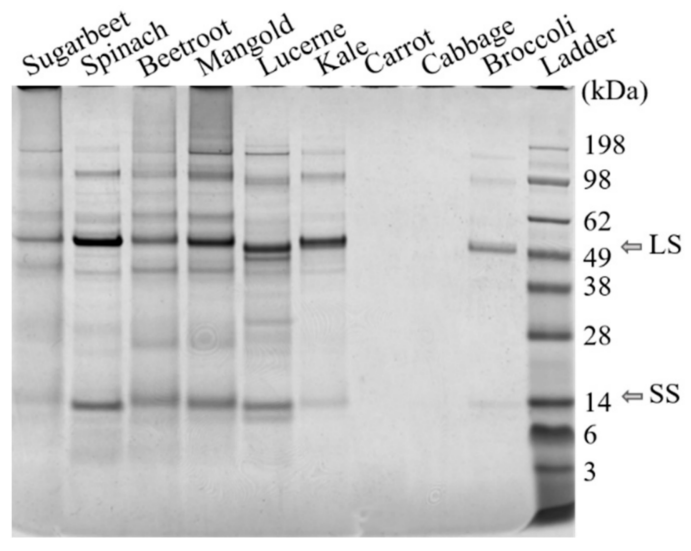

Figure 3. Results of SDS-PAGE analysis of freeze-dried white protein isolates (S4, see Figure 2) dissolved in water. The RuBisCO subunits are at $\sim 55 \mathrm{kDa}$ and $\sim 14 \mathrm{kDa}$. LS: large subunit, SS: small subunit.

The protein fractionation results also differed significantly for the biomass types that were successfully fractionated (Table 2a), confirming that biomass source had a large impact on the outcome of the fractionation process. Presence of RuBisCO was detected in all biomass types, in the white juices (Figure 4, Supplementary Figure S1), and in the white protein fraction of the substrates for which the process was successful (Figure 3). Of the nine biomass types evaluated, mangold leaves resulted in the highest $\mathrm{N}$ yield after the full process, with $1.9 \%$ of initial $\mathrm{N}$ in the biomass recovered in the white extract (S4) (Table 2a). The corresponding value for lucerne, the crop with the second highest level, was $1.5 \%$. The highest yield of soluble $\mathrm{N}$ from the particle-free green juice (S1) to the final white protein (S4) (Supplementary Table S1) was seen for sugarbeet (7.5\%). Previous studies evaluating white protein extracts from green biomass often report higher yields than those obtained in the present study. However, comparison of $\mathrm{N}$ yields between studies was hampered by the fact that (i) extraction methods generally differ between studies, (ii) a limited number of crop biomass types (mainly sugarbeet, lucerne, and spinach) have been extensively studied in this regard, and (iii) different combinations of methods and fractions are used for the calculations. Thus, results are rarely comparable in practice. In a previous study, juicing of sugarbeet leaves followed by acid and heat precipitation of the white protein fraction (a 
procedure partly comparable to steps 1 and 5 in Figure 2) resulted in $\mathrm{N}$ yield of $25 \%$ [16]. In another study using sugarbeet leaves, heat precipitation of the green protein fraction and ultracentrifugation to concentrate the white protein (steps 1 and 4 in Figure 2) resulted in $\mathrm{N}$ yield of $\sim 12 \%$ [11]. Thus, the fraction used to determine the $\mathrm{N}$ yield in those two studies was the most similar to our S2 fraction (WJ), but not our final resolubilized extract S4 (Table 2a). The $\mathrm{N}$ yield in S2 in the present study was $24.6 \%$ for mangold, $20.0 \%$ for lucerne, and $11.7 \%$ for sugarbeet, which is comparable to previous findings $[11,16]$.

Table 2. (a) Yield (\%) of nitrogen (N) relative to $\mathrm{N}$ content in initial biomass (BM) in the different process steps (see Figure 2). Mean of three process replicates (unless otherwise indicated by superscript numbers). (b) Yield (\%) of $\mathrm{N}$ relative to the ingoing material for each process step. (c) $\mathrm{N}$ content (\%) on a dry matter basis (average of replicates) of the flows in the extraction process. Different letters (A-D) indicate significant differences $(p<0.05)$ in yield. Superscript numbers indicate numbers of replicates if not triplicates. GJ: green juice, $\mathrm{GJ}_{\mathrm{sp}}$ : green juice from the second press, S1: particle-free green juice, $\mathrm{P}_{\mathrm{fp}}$ : pellet with freeze-thaw precipitate, $\mathrm{S} 2$ : supernatant after thermal treatment, $\mathrm{P} 3$ : acid-precipitated white protein, $\mathrm{S} 4$ : resolubilized protein fraction, $\mathrm{P} 4$ : insoluble fraction.

\begin{tabular}{|c|c|c|c|c|c|c|c|c|c|c|c|}
\hline (a) & \multicolumn{11}{|c|}{ Process Step } \\
\hline $\begin{array}{l}\text { Yield of } \\
\text { N (\%) }\end{array}$ & \multicolumn{2}{|c|}{ BM Pressing } & \multicolumn{2}{|c|}{ Second BM Pressing } & $\begin{array}{l}\text { Separation } \\
\text { of Particles }\end{array}$ & $\begin{array}{c}\text { Thermal } \\
\text { Precipitation }\end{array}$ & \multicolumn{2}{|c|}{ Acid Precipitation } & \multicolumn{3}{|c|}{ Full Process } \\
\hline Biomass & \multicolumn{2}{|c|}{$\mathrm{BM}$ to $\mathrm{GJ}$} & \multicolumn{2}{|c|}{$\mathrm{BM}$ to $\mathrm{GJ}_{\mathrm{sp}}$} & $\mathrm{BM}$ to $\mathrm{S} 1$ & $\mathrm{BM}$ to $\mathrm{S} 2$ & \multicolumn{2}{|c|}{ BM to P3 } & \multicolumn{3}{|c|}{$\mathrm{BM}$ to $\mathrm{S} 4$} \\
\hline Broccoli & \multicolumn{2}{|c|}{$28.2 \pm 2.0^{\mathrm{BC}}$} & \multicolumn{2}{|c|}{$7.2 \pm 1.5^{\mathrm{BC}}$} & $14.8 \pm 1.4^{\mathrm{BC}}$ & $15.5 \pm 2.2^{\mathrm{B}}$ & \multicolumn{2}{|c|}{$2.9 \pm 0.7 \mathrm{CD}$} & \multicolumn{3}{|c|}{$0.4 \pm 0.0^{\mathrm{A}}$} \\
\hline Cabbage & \multicolumn{2}{|c|}{$37.4 \pm 5.4^{\mathrm{C}}$} & \multicolumn{2}{|c|}{$7.9 \pm 2.0^{\mathrm{BC}}$} & $9.3 \pm 2.4^{\mathrm{AB}}$ & $14.4 \pm 3.1^{\mathrm{AB}}$ & \multicolumn{2}{|c|}{$0.2 \pm 0.1 \mathrm{AB}$} & \multicolumn{3}{|c|}{$0.2 \pm 0.1^{\mathrm{A}}$} \\
\hline Kale & \multicolumn{2}{|c|}{$30.3 \pm 3.3^{\mathrm{BC}}$} & \multicolumn{2}{|c|}{$5.0 \pm 0.2 \mathrm{AB}$} & $19.3 \pm 0.7^{\mathrm{CD}}$ & $18.7 \pm 0.7^{\mathrm{BC}}$ & \multicolumn{2}{|c|}{$2.1 \pm 0.2 \mathrm{ABCD}$} & \multicolumn{3}{|c|}{$0.5 \pm 0.1^{\mathrm{AB}}$} \\
\hline Mangold & \multicolumn{2}{|c|}{$53.1 \pm 1.0^{\mathrm{D}}$} & \multicolumn{2}{|c|}{$8.4 \pm 0.6^{C}$} & $36.9 \pm 1.3^{\mathrm{E}}$ & $24.6 \pm 4.6^{\mathrm{C}}$ & \multicolumn{2}{|c|}{$3.7 \pm 1.6^{\mathrm{D}}$} & \multicolumn{3}{|c|}{$1.9 \pm 1.1^{\mathrm{B}}$} \\
\hline Beetroot & 35. & $=2.1^{\mathrm{C}}$ & $6.3 \pm$ & $.4 \mathrm{ABC}$ & $21.9 \pm 2.1^{\mathrm{D}}$ & $17.5 \pm 0.3^{\mathrm{BC}}$ & $3.8=$ & $.1^{\mathrm{D}}$ & & $1.0 \pm 0.5^{\mathrm{AB}}$ & \\
\hline Sugarbeet & 14. & $=4.0^{\mathrm{A}}$ & $3.7=$ & $0.6^{\mathrm{A}}$ & $12.1 \pm 1.5^{\mathrm{AB}}$ & $11.72 \pm 2.4^{\mathrm{AB}}$ & $1.2^{2} \pm$ & $.3^{\mathrm{ABC}}$ & & $0.9^{2} \pm 0^{\mathrm{AB}}$ & \\
\hline Carrot & 20.9 & $2.7^{\mathrm{AB}}$ & $5.3=$ & $.4^{\mathrm{AB}}$ & $6.0 \pm 0.5^{\mathrm{A}}$ & $7.2 \pm 0.4^{\mathrm{A}}$ & 0.2 & $.2^{\mathrm{A}}$ & & $0.1 \pm 0.1^{\mathrm{A}}$ & \\
\hline Lucerne & 52. & $=5.4^{\mathrm{D}}$ & 15.1 & $0.9^{\mathrm{D}}$ & $42.9 \pm 4.4^{\mathrm{E}}$ & $20.0 \pm 0.9^{\mathrm{BC}}$ & 3.3 & & & $1.5^{1 \mathrm{AB}}$ & \\
\hline Spinach & 27.6 & $5.0^{\mathrm{BC}}$ & 8.9 & $1.3^{\mathrm{C}}$ & $25.1 \pm 0.4^{\mathrm{D}}$ & $18.0 \pm 3.8^{\mathrm{BC}}$ & $3.0^{2} \pm$ & $.1^{C D}$ & & $1.0^{2} \pm 0.4^{\mathrm{AB}}$ & \\
\hline (b) & & & & & & Process Step & & & & & \\
\hline $\begin{array}{c}\text { Yield of } \\
\text { N (\%) }\end{array}$ & $\begin{array}{r}\text { Sep } \\
\mathbf{P}\end{array}$ & $\begin{array}{l}\text { tion of } \\
\text { icles }\end{array}$ & Separatio & of Freeze-7 & aw Precipitate & Ther & l Precipitat & & & cid Precipitat & \\
\hline Biomass & & o S1 & & $\mathrm{S} 1$ to $\mathrm{P}$ & & & $\mathrm{S} 1$ to $\mathrm{S} 2$ & & & S2 to P3 & \\
\hline Broccoli & 52.6 & $4.2^{\mathrm{AB}}$ & & $12.6 \pm 1$. & & & $2 \pm 0.5^{\mathrm{CD}}$ & & & $18.8 \pm 1.7^{\mathrm{BC}}$ & \\
\hline Cabbage & 24. & $=5.9^{\mathrm{A}}$ & & $42.2 \pm 14$ & & & $9 \pm 1.8^{\mathrm{DE}}$ & & & $1.2 \pm 1.1^{\mathrm{A}}$ & \\
\hline Kale & 64.1 & $6.4^{\mathrm{BC}}$ & & $6.5 \pm 1.4$ & & & $3 \pm 2.5^{\mathrm{CD}}$ & & & $11.4 \pm 1.2^{\mathrm{B}}$ & \\
\hline Mangold & 69.6 & $3.6^{\mathrm{BC}}$ & & $4.6 \pm 3$. & & & $.0 \pm 6.0^{\mathrm{A}}$ & & & $15.2 \pm 5.4^{\mathrm{BC}}$ & \\
\hline Beetroot & 61.6 & $3.5^{\mathrm{BC}}$ & & $6.0 \pm 6.0$ & & & $9 \pm 16.1^{C D}$ & & & $21.6 \pm 0.3^{C}$ & \\
\hline Sugarbeet & 79.7 & $31.4^{\mathrm{BC}}$ & & $1.2 \pm 0.2$ & & & $\pm 13.2 \mathrm{ABC}$ & & & $10.5^{2} \pm 0.5^{\mathrm{AI}}$ & \\
\hline Carrot & 29.2 & $=5.1^{\mathrm{A}}$ & & $1.8 \pm 0.1$ & & & $0.6 \pm 8.0^{\mathrm{E}}$ & & & $2.8 \pm 2.4^{\mathrm{A}}$ & \\
\hline Lucerne & 82.5 & $8.5^{\mathrm{BC}}$ & & $7.7 \pm 1.5$ & & & $2 \pm 4.4^{\mathrm{AB}}$ & & & $16.1^{1 \mathrm{BC}}$ & \\
\hline Spinach & 93.3 & $17.9^{\mathrm{C}}$ & & $7.1 \pm 0.7$ & & & $\pm 10.1^{\mathrm{BCD}}$ & & & $16.9^{2} \pm 4.0^{\mathrm{BC}}$ & \\
\hline (c) & & & & & & & & & & & \\
\hline$\% \mathrm{~N}$ & & & & & & low in the Pro & & & & & \\
\hline Biomass & $\mathbf{B M}^{*}$ & GJ & Pulp & $\mathrm{GJ}_{\mathrm{sp}}$ & Pulp $_{\text {sp }}$ & S1 & $\mathbf{P}_{\mathrm{fp}}$ & S2 & P3 & S4 & P4 \\
\hline Broccoli & 3.2 & $2.1 \pm 0.1$ & $1.9 \pm 0.2$ & $2.4 \pm 0.1$ & $1.9 \pm 0.2$ & $1.7 \pm 0.1$ & $5.8 \pm 0.2$ & $2.0 \pm 0.2$ & $7.9 \pm 0.2$ & $1.8 \pm 0.4$ & $13.6 \pm 0.2$ \\
\hline Cabbage & 2.1 & $1.7 \pm 0.2$ & $1.2 \pm 0.1$ & $1.5 \pm 0.3$ & $1.3 \pm 0.2$ & $0.5 \pm 0.1$ & $8.2 \pm 0.3$ & $0.8 \pm 0.2$ & $1.2 \pm 0.0$ & $0.9 \pm 0.1$ & $0.7 \pm 0.5$ \\
\hline Kale & 3 & $2.7 \pm 0.2$ & $1.5 \pm 0.2$ & $2.9 \pm 0.1$ & $2.2 \pm 0.1$ & $2.2 \pm 0.0$ & $1.7 \pm 0.1$ & $2.3 \pm 0.1$ & $7.9 \pm 0.4$ & $2.6 \pm 0.4$ & $12.3 \pm 1.2$ \\
\hline Mangold & 2.1 & $2.3 \pm 0.1$ & $2.4 \pm 0.4$ & $2.6 \pm 0.2$ & $1.4 \pm 0.1$ & $1.9 \pm 0.2$ & $4.3 \pm 0.3$ & $1.6 \pm 0.3$ & $7.2 \pm 0.6$ & $3.6 \pm 0.9$ & $13.7 \pm 0.4$ \\
\hline Beetroot & 3.2 & $3.0 \pm 0.0$ & $3.3 \pm 0.2$ & $3.6 \pm 0.1$ & $1.6 \pm 0.2$ & $2.6 \pm 0.1$ & $5.5 \pm 0.3$ & $2.2 \pm 0.1$ & $9.2 \pm 0.7$ & $3.3 \pm 0.7$ & $14.0 \pm 0.3$ \\
\hline Sugarbeet & 3 & $1.1 \pm 0.2$ & $1.3 \pm 0.3$ & $1.6 \pm 0.2$ & $2.6 \pm 0.5$ & $1.0 \pm 0.1$ & $5.7 \pm 0.4$ & $1.1 \pm 0.1$ & $2.6^{2} \pm 1.5$ & $2.3^{2} \pm 0.9$ & $0.5^{2} \pm 0.1$ \\
\hline Carrot & 2.5 & $1.5 \pm 0.1$ & $2.1 \pm 0.0$ & $2.3 \pm 0.1$ & $3.2 \pm 0.3$ & $0.6 \pm 0.1$ & $8.0 \pm 0.2$ & $0.6 \pm 0.0$ & $1.1 \pm 0.4$ & $0.6 \pm 0.1$ & \\
\hline Lucerne & 2.8 & $3.8 \pm 0.3$ & $2.0 \pm 0.1$ & $4.1 \pm 0.1$ & $5.1 \pm 0.2$ & $4.3 \pm 0.1$ & $8.0 \pm 0.0$ & $3.2 \pm 0.1$ & 7.21 & 4.01 & 12.91 \\
\hline Spinach & 5.1 & $4.4 \pm 0.3$ & $4.9 \pm 0.2$ & $4.1 \pm 0.1$ & $1.5 \pm 0.3$ & $4.2 \pm 0.3$ & $2.9 \pm 0.5$ & $4.0 \pm 0.2$ & $8.1 \pm 1.8$ & $3.3 \pm 0.5$ & $14.1 \pm 0.5$ \\
\hline
\end{tabular}

* Biomass $\mathrm{N}$ composition was assumed to be the same in all process replicates. Standard deviations for biomass \% $\mathrm{N}$ are found in Table 1.

Mangold and lucerne not only had the highest $\mathrm{N}$ yields in this study, but also the highest $\mathrm{N}$ content in the white protein isolate (S4), with values of $4.0 \%$ and $3.6 \%$, respectively (Table 2c). Higher $\mathrm{N}$ content has been reported in other studies fractionating white protein from sugarbeet, e.g., 9.6\% and 7.6\% [16,28], and from lucerne, e.g., $11.2 \%, 10.7 \%$, $11.8 \%$, and $14.8 \%[11,15,24,37]$. As noted above for $\mathrm{N}$ yield, comparisons between studies are difficult, although a product mostly corresponding to fraction P3 in this study is often used as an end-point in other studies. The N content in P3 was between 5.1 and 12.5\% for the different crops evaluated, corresponding well with previous findings. 


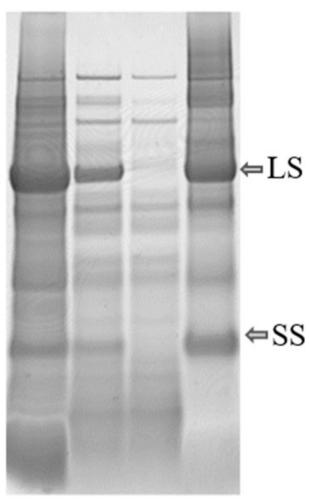

Figure 4. Protein content in mangold leaves, as determined by SDS-PAGE analysis of supernatants S1-S4 from the extraction process (see Figure 2). LS: large subunit, SS: small subunit of RuBisCO.

To understand and characterize the background and reasons for differences in protein fractionation between the nine green biomass types studied, in this study additional steps were included in the standard fractionation method (as outlined in Figure 2).

\subsection{Differences in Protein Fractionation between Biomass Types}

\subsubsection{Juice Pressing}

Juice pressing resulted in large variation between the crops in terms of $\mathrm{N}$, total mass, wet mass, dry matter, and $\mathrm{N}$ yield, etc., from the biomass to GJ (Table 2), even for crops of the same species, e.g., for the Beta vulgaris varieties the $\mathrm{N}$ yield ranged from $15 \%$ for sugarbeet to $53 \%$ for mangold (Table 2, Supplementary Table S1). Variation in N yield between the biomass types evaluated in this study may be partly explained by structural differences in the biomass of various crops in terms of cell wall strength and water content. Previous studies have shown a significant negative correlation between maturity and protein extractability in other crops, e.g., clover, timothy, and chicory [38], so differences in maturity and cell wall thickness might also partly explain the differences between crops in this study. Therefore, factors such as biomass structural features, crop maturity, and cell wall thickness should be considered in industrial applications involving green biomass protein fractionation, especially when using crops, such as lucerne, which may be harvested several times during the season.

Higher total $\mathrm{N}$ yields were achieved from all biomass types when an additional juicing step was included (i.e., adding water to the extruded pulp and re-feeding it to the screw press), although the recovery varied (Table 2a). The effect was most prominent for lucerne, where the second press resulted in an $\mathrm{N}$ yield of $15 \%$ from $\mathrm{BM}$ to $\mathrm{GJ}_{\mathrm{sp}}$. This increased the total $\mathrm{N}$ yield from juicing of lucerne to $67 \%\left(\mathrm{GJ}+\mathrm{GJ}_{\mathrm{sp}}\right)$, which is similar to previous findings of $47 \%$ and $50 \% \mathrm{~N}$ yield in GJ for lucerne [24,25] and $69 \%$ for sugarbeet [18]. A second press caused further cell disruption, which released soluble proteins, and the added water carried the protein into the $\mathrm{GJ}_{\mathrm{sp}}$, which is critical when aiming for high $\mathrm{N}$ yield [25]. Overall, lucerne gave the highest $\mathrm{N}$ yield and carrot and sugarbeet the lowest after the two presses, with all cases showing substantially increased total $\mathrm{N}$ extraction from $\mathrm{BM}$ after the second pressing. Thus, a second juice pressing was beneficial for all biomass types evaluated, increasing the efficiency of the protein fractionation process.

Solid particles in the GJ were removed through centrifugation, resulting in a substantially particle-free green juice (S1) that was still green in color for all biomass types. This step was added to examine how water-soluble white proteins were separated in the following thermal precipitation step, in which any particles present in the GJ would be separated together with the green protein fraction. The centrifugation step was identified as the main reason for the unsuccessful protein fractionation of carrot and cabbage, resulting in low white protein yield. Less than $30 \%$ of the protein content in GJ was found in S1 after the centrifugation step for these two crops. For all other crops the transfer rate from 
GJ to $\mathrm{S} 1$ exceeded $50 \%$, which corresponds to results reported for lucerne in a previous study [25]. The highest GJ to $S 1$ recovery rates were found for spinach, lucerne (both $\sim 80 \%$ ), and sugarbeet $(>90 \%)$. The low rates found for cabbage and carrot indicated poor cell breakage, high content of proteins bound to, or contained in, solid particles/organelles, or high content of insoluble proteins. This issue needs to be resolved for crops such as cabbage and carrot before they are suitable green biomass substrates for protein fractionation.

\subsubsection{Green Protein Fractionation and White Juice Production}

There were differences in thermal coagulation behavior of GJ from the different green biomass types, as indicated by the optimal temperature for precipitating the green proteins while simultaneously keeping the white protein in the WJ (Figure 5). The RuBisCO subunits (around $55 \mathrm{kDa}$ and $14 \mathrm{kDa}$ ) and most other proteins in all biomass types were generally unaffected by heating for $25 \mathrm{~min}$ at temperatures of up to $50^{\circ} \mathrm{C}$, while protein bands started to disappear (precipitate together with the green proteins) at $50-55^{\circ} \mathrm{C}$ and disappeared (precipitated fully) at $60-65^{\circ} \mathrm{C}$ (Figures 5 and 6). The reason for the weak reappearance of the RuBisCO large subunit at $80^{\circ} \mathrm{C}$ for some biomass types (e.g., broccoli and sugarbeet; Figure 6) is unclear but could possibly be a result of the two subunits dissociating at higher temperature, and a difference in the solubility of the two subunits at these temperatures. The clearest difference between the biomass types with regard to precipitation temperature of RuBisCO was the upper temperature for full precipitation. RuBisCO was still present to some extent at $55{ }^{\circ} \mathrm{C}$ in all biomass types evaluated (Figure 5, Supplementary Figure S1), but at $65^{\circ} \mathrm{C}$ RuBisCO was still only clearly present in the spinach sample. Similarities in response to thermal treatment (e.g., changes in protein composition and concentration) were seen for crops of the same family, e.g., the three varieties of Beta vulgaris (sugarbeet, beetroot, and mangold) and the two successfully extracted Brassica species (broccoli and kale). The Beta vulgaris varieties showed relatively low protein thermal stability, with a clear drop in protein concentration at $55^{\circ} \mathrm{C}$ (Figure 5) and a noticeable decrease in the intensity of the RuBisCO bands at temperatures above $50^{\circ} \mathrm{C}$ (Supplementary Figure S1). A similar concentration drop at $55^{\circ} \mathrm{C}$ was observed for kale and broccoli (Figure 5), but the band intensity was intact at temperatures up to $55^{\circ} \mathrm{C}$ (Supplementary Figure S1), indicating greater thermal stability of RuBisCO in Brassica biomass. Previous studies have determined the denaturation temperature of RuBisCO from lucerne to be between $61.85^{\circ} \mathrm{C}$ and $66.85^{\circ} \mathrm{C}$, depending on the environment [39], and that of RuBisCO from spinach to be $64.9^{\circ} \mathrm{C}$ [20]. Thus, differences in denaturation and precipitation of RuBisCO in the biomass types examined in this study might be explained by the environment of the protein, with the S1 matrix affecting the stability and thermosensitivity of RuBisCO and other proteins present. For successful thermal protein precipitation, the optimal temperature may have to be determined for each biomass type to be used in an industrial process.
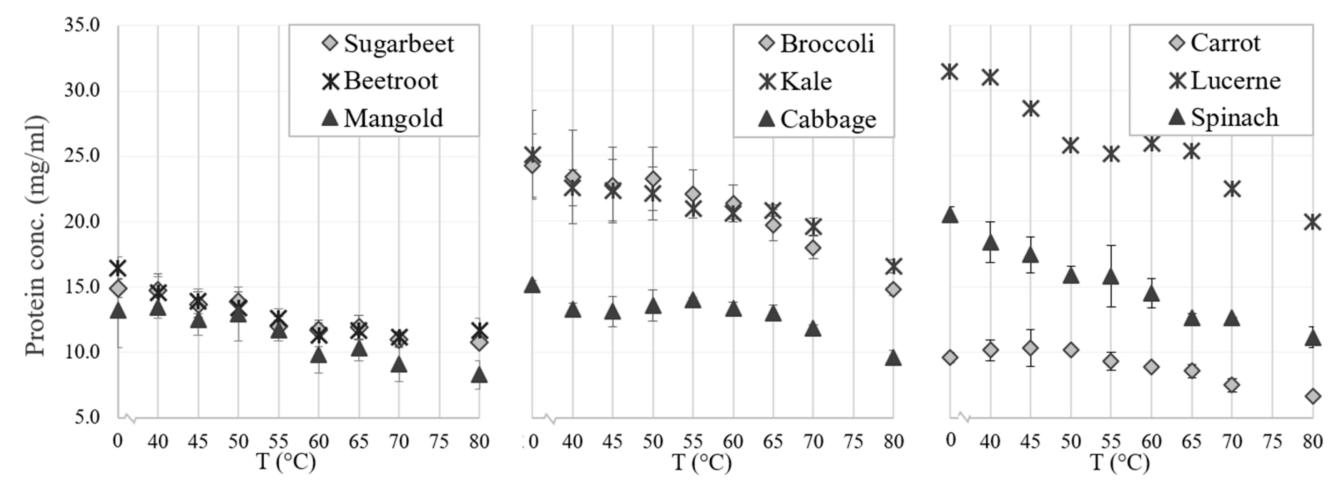

Figure 5. Effects of thermal treatment temperature on protein concentration (analyzed with the bicinchoninic acid method) in particle-free supernatant (fraction S1) from crop biomass. 


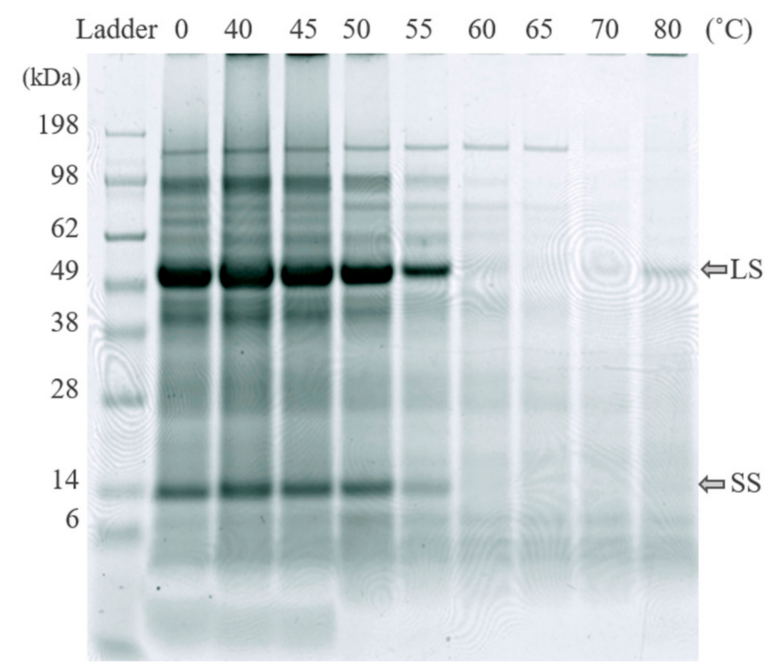

Figure 6. Effects of thermal treatment temperature on protein composition (analyzed using SDSPAGE) in particle-free supernatant (fraction S1) from sugarbeet biomass. LS: large subunit, SS: small subunit of RuBisCO.

Effects of duration of thermal treatment on protein precipitation from $\mathrm{S} 1$ of the different biomass types were not assessed in detail, but initial experiments indicated that thermal treatment duration may be important (results not shown). Previous studies have reported that lucerne GJ treated at $50^{\circ} \mathrm{C}$ for $5 \mathrm{~min}$ is still green, but after $20 \mathrm{~min}$ the supernatant is clear [26], and that heating sugarbeet GJ at $55^{\circ} \mathrm{C}$ for 5 min gives higher white protein yield than heating for $10 \mathrm{~min}$ [28]. Further studies are required to identify the optimal time and temperature settings for each of the nine biomass types evaluated here.

The $\mathrm{N}$ yield obtained from thermal precipitation (relative amount of N in S1 transferred to fractions S2 and P2) differed significantly between the biomass types. The $\mathrm{N}$ yield from S1 to S2 exceeded $80 \%$ for all biomass types except lucerne, mangold, and sugarbeet, for which the yield was considerably lower (52-61\%) (Table $2 b)$. These differences likely reflect variation in thermal sensitivity of the multiple proteins in S1 of the different biomass types.

\subsubsection{Acid Precipitation of the White Protein Fraction}

The $\mathrm{N}$ yield from acid precipitation at $\mathrm{pH} 4.5$ (S2 to $\mathrm{P} 3$ ) varied between $10.5 \%$ and $21.5 \%$ for most biomass types, but the values for cabbage and carrot were considerably lower $(1.2 \%$ and $2.8 \%$, respectively) (Table $2 \mathrm{~b}$ ). The $\mathrm{N}$ content of the acid-precipitated protein in the resulting pellet (P3) was around $8 \%$ for all crops except cabbage, carrot, and sugarbeet, for which the value was between $1.1 \%$ and $2.6 \%$ (Table 2c). Low $\mathrm{N}$ yield and $\mathrm{N}$ content of cabbage and carrot after precipitation was expected, based on the low yields already observed during particle separation of GJ to obtain S1 (i.e., low BM to S1 value; Table 2a). For the other biomass types, variations in precipitated protein amount may be the result of differences in the most suitable $\mathrm{pH}$ for precipitation. Previous studies have reported $\mathrm{pH} 4$ or lower as optimal for precipitation of proteins in sugarbeet $[23,24]$ and pH 3.5 as optimal for lucerne proteins [37].

Particle size measurements and pI determinations confirmed that proteins from the different biomass types responded differently to variations in $\mathrm{pH}$ (Figure 7). Differences were even seen between varieties, e.g., the particle size of beetroot aggregates increased drastically at $\mathrm{pH} 4.5$ and those of sugarbeet at $\mathrm{pH}$ 3.5. Data on $\mathrm{pI}$ values and on solubility of the full $\mathrm{S} 2$ fraction have not been reported previously, but the $\mathrm{pH}$ for minimum solubility of the final white protein concentrates has been reported to be e.g., 3.5 for soy bean leaves [40], 4 for spinach [31], and 5 for sugarbeet [11]. 

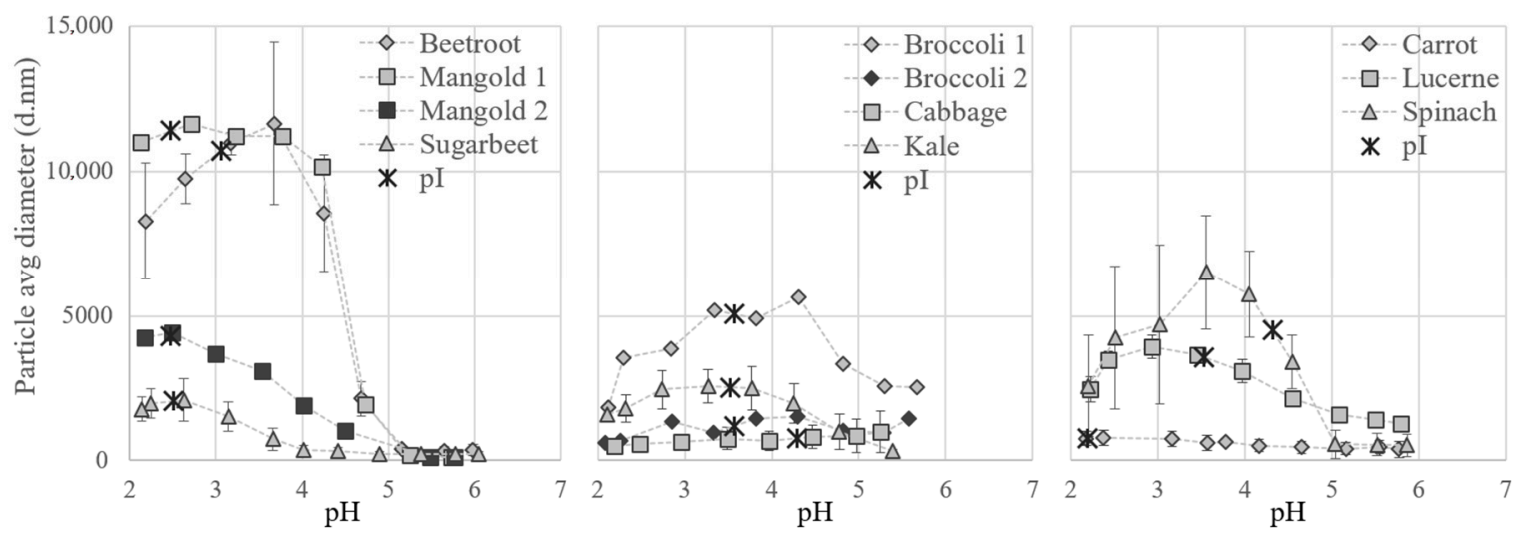

Figure 7. Particle size of white protein in thermally treated supernatant (fraction S2) from the different crops at different $\mathrm{pH}$ values during titration. Isoelectric point $(\mathrm{pI})$ of $\mathrm{S} 2$ is marked on the respective curve.

For all crops evaluated except cabbage, protein aggregates were formed during titration with acid and the particles generally increased in size at $\mathrm{pH}$ values just below 5 and decreased in size at values below 2.5 (Figure 7). Precipitation, causing the formation of particles, occurs when the charge on amino acids reaches a net zero state; the isoelectric point (pI) [41]. The $\mathrm{pI}$ for the $\mathrm{S} 2$ fractions from the different crops ranged between 2.2 and 4.3 , according to the zeta potential measurements (Figure 7). The $\mathrm{pI}$ for spinach S2 was 4.3, which is considerably lower than the theoretical $\mathrm{pI}$ value for pure spinach RuBisCO of 6.03 . This discrepancy is most likely related to the presence of other proteins and compounds in the solution, which would have a large effect on the net charge.

The minimum solubility, and also the largest aggregates of the proteins, were expected around the $\mathrm{pI}$, but for several of the crops the particle size increased before $\mathrm{pI}$ was reached during titration. This indicates that some proteins present, e.g., RuBisCO, started to precipitate earlier in the titration, i.e., at higher $\mathrm{pH}$. For example, precipitation of RuBisCO from mangold clearly occurred at pH 4.5 (see Figure 4), since RuBisCO was not present in S3 but was present in S2, even though the maximum particle size (measured by dynamic light scattering) occurred close to $\mathrm{pH} 2.5$ (Figure 7), which was the $\mathrm{pI}$ of the overall solution.

To achieve sufficient separation of white proteins, the particle size did not necessarily need to reach the maximum. For all biomass types studied here, aggregation was initiated at $\mathrm{pH} 4.5$ (the $\mathrm{pH}$ used for precipitation of the white proteins). When acid precipitation is chosen as a method for separating white proteins in a biorefinery set-up, the same $\mathrm{pH}$ could be used for different biomass types, but the yields would most likely benefit from individual adjustments.

\subsubsection{Resolubilization of the White Protein Fraction}

The $\mathrm{N}$ content in the resulting resolubilized, neutralized, and freeze-dried white protein concentrate (S4) varied for the different biomass types evaluated. It was highest for lucerne $(4 \%)$ and lowest for carrot and cabbage ( $0.6 \%$ and $0.9 \%$, respectively) (Table $2 \mathrm{c}$ ). Again, the low levels for carrot and cabbage were the result of incomplete protein fractionation in earlier steps of the process. The other biomass types resulted in white protein concentrates with $\mathrm{N}$ content ranging from $2.3 \%$ to $3.6 \%$. Higher $\mathrm{N}$ content could be achieved by adding a washing step for the acid-precipitated protein (P3) prior to resolubilization, as this would remove some of the co-precipitated compounds present. Several factors are known to have an impact on resolubilization of the white protein fraction, including $\mathrm{pH}$, treatment temperature, use of enzymes, enzyme inhibitors, and adsorptive resins that influence the impact of phytochemicals on protein resolubilization [22,40,42,43]. The variation in protein resolubilization of the $\mathrm{P} 3$ fraction between biomass types might thus be the result of differences in phytochemicals binding to the proteins. Use of enzymes or enzyme inhibitors might result in more similar white protein yield for different biomass types. 


\subsection{Use of Green Biomass in Industrial Protein Fractionation for Food Ingredients, Additives, and Products}

The long-term goal behind the present study was a desire to set up an industrial process for protein fractionation of green biomass that could contribute high-value food ingredients, additives and products. Such a process would require green biomass, from a range of different sources, to be available throughout the year. Additionally, such an upscaling would require a protocol suitable for a large range of green biomass types, to allow for maximum facility utilization throughout the year. Therefore, a general protocol based on literature methods $[18,24,28,31]$ was used in this study. However, the present study clearly revealed differences in protein fractionation between green biomass of different origin, suggesting a need for a crop-specific (and eventually also growth stage-specific) fractionation procedure in order to achieve successful production of high-value proteins suitable for food. This study identified important steps to consider for industrial protein fractionation of each of the biomass types, although individual biomass-based settings in an industrial production plant may result in higher production costs. A year-round availability of green biomass, of similar growth stage, would also require large storage facilities for e.g., frozen [44] or silage green biomass. Such a storage will also highly affect the costs (storage of frozen biomass) or destroy the proteins (silage).

Analysis of the protein composition by SDS-PAGE (Figures 3 and 4) showed a high content of RuBisCO in the initial particle-free green juice (S1), the thermally treated S1 (S2), and the final resolubilized protein (S4), while the supernatant remaining after acid precipitation (S3) contained negligible amounts, indicating successful RuBisCO separation. From a food perspective, the RuBisCO-rich white protein concentrate is highly interesting, as it is known to be highly nutritious and have promising functional food properties [11-13]. However, the green protein fraction (P1 combined with P2) and other fractions obtained from the protein fractionation might also be relevant co-products, not least for further fractionation of interesting compounds. Phenolic compounds were present to various degrees in all fractions (data not shown), and these might be of interest as antioxidant-enriched products or for further fractionation before use in food and biomedical applications $[45,46]$. Fractionation of additional high-value compounds from the green biomass may contribute positively to the economy for the whole process [46].

\section{Conclusions}

Green biomass source substantially influenced the outcome, when a general protein fractionation procedure was applied to extract high-quality protein for use by the food industry. White protein concentrate rich in RuBisCO was extractable from a majority of nine green leafy biomass types subjected to general fractionation, although with considerable variation in protein yield and quality. Biomass type affected protein yield all fractionation steps, i.e., juicing, thermal precipitation, acid precipitation, and resolubilization. Factors such as biomass structural features, crop maturity, and cell wall thickness probably affected the outcome of the juicing step, with stronger structures needing harsher treatment. Protein from the different biomass sources associated to particles in the green juice to varying degrees, with a strong association of proteins for carrot and cabbage leaves, resulting in low yield of high-quality food protein. Modification of the protein fractionation procedure is required to release such protein in these biomass types.

The biomass matrix influenced the thermosensitivity of RuBisCO and other proteins present in the biomass and was important for the thermal precipitation step. Similarities in thermosensitivity were seen for biomass of related origin, e.g., proteins from different varieties of Beta vulgaris were generally more sensitive to heat than proteins from, e.g., lucerne. For biomass of sugarbeet, lucerne, kale, and broccoli, $\mathrm{pH}<4.5$ was most suitable for acid precipitation, while for mangold, beetroot and spinach $\mathrm{pH}$ of 4.5 was most suitable. This indicates that differences in the protein environment influenced acid precipitation behavior, as RuBiSCO theoretically precipitates at around $\mathrm{pH} 6$. 
In a biorefinery context, use of a general procedure, but with some parameters modified for each new biomass type, would improve the final outcome compared with using a general procedure for all green leafy biomass.

Supplementary Materials: The following are available online at https:/ /www.mdpi.com/article/10 .3390 /foods10112533/s1, Figure S1: SDS-PAGE analyses of thermally treated particle free green juice (S2), Figure S2: Visualization of $\mathrm{N}$ yields in some of the process steps for the different biomass types, Table S1: Yields (in \%) of total mass (m), dry matter (DM), and nitrogen (N), in the white protein extraction process.

Author Contributions: Conceptualization, A.-L.N., W.R.N. and E.J.; methodology, A.-L.N.; software, A.-L.N.; validation, A.-L.N., W.R.N. and E.J.; formal analysis, A.-L.N.; investigation, A.-L.N.; resources, E.J.; data curation, A.-L.N.; writing—original draft preparation, A.-L.N.; writing—review and editing, A.-L.N., W.R.N. and E.J;; visualization, A.-L.N.; supervision, W.R.N. and E.J; project administration, E.J.; funding acquisition, E.J. All authors have read and agreed to the published version of the manuscript.

Funding: This work was supported by the Swedish strategic research area "Trees and Crops for the Future (TC4F)".

Institutional Review Board Statement: Not applicable.

Informed Consent Statement: Not applicable.

Data Availability Statement: Not applicable.

Acknowledgments: Thanks go to Arno Wouters, for guidance in the zeta and size measurement setup, and Jan Delcour, both at Laboratory of Food Chemistry and Biochemistry, Department of Molecular and Microbial Systems, KU Leuven, Belgium, for kindly providing equipment access.

Conflicts of Interest: The authors declare no conflict of interest. The funders had no role in the design of the study; in the collection, analyses, or interpretation of data; in the writing of the manuscript, or in the decision to publish the results.

\section{References}

1. Barclays. Carving Up the Alternative Meat Market. Available online: https://www.investmentbank.barclays.com/our-insights/ carving-up-the-alternative-meat-market.html (accessed on 6 July 2020).

2. Smart Protein Project. Plant-Based Foods in Europe: How Big Is the Market? Smart Protein Plant-Based Food Sector Report by Smart Protein Project, European Union's Horizon 2020 Research and Innovation Programme (No 862957). 2020. Available online: https://knowledge4policy.ec.europa.eu/publication/plant-based-foods-europe-how-big-market_en (accessed on 12 October 2021).

3. Furu, M. Marknadsanalys och Potential för Växtbaserade Proteiner. 2020. Available online: https://www.lrf.se/globalassets/ dokument/mitt-lrf/nyheter/2020/marknadsanalys-och-potential-for-vaxtbaserade-proteiner.pdf (accessed on 27 March 2020).

4. USDA. Oilseeds: World Markets and Trade; Monthly Report July 2021; United States Department of Agriculture: Economics, Statistics and Market Information System: Washington, DC, USA, 2021. Available online: https://usda.library.cornell.edu/ concern/publications/tx31qh68h?locale=en (accessed on 16 August 2021).

5. Sozer, N.; Poutanen, K. Plant protein ingredients for future foods. Agro FOOD Ind. Hi-Tech 2015, 26, 56-59.

6. Pirie, N.W. The direct use of leaf protein in human nutrition. Chem. Ind. 1942, 61, 45-48.

7. Di Stefano, E.; Agyei, D.; Njoku, E.N.; Udenigwe, C.C. Plant RuBisCo: An underutilized protein for food applications. J. Am. Oil Chem. Soc. 2018, 95, 1063-1074. [CrossRef]

8. Van de Velde, F.; Alting, A.; Pouvreau, L. From waste product to food ingredient: The extraction of abundant plant protein RuBisCo. New Food 2011, 14, 10-13.

9. Berndtsson, E.; Nynäs, A.-L.; Newson, W.R.; Langton, M.; Andersson, R.; Johansson, E.; Olsson, M.E. The underutilised side streams of broccoli and kale-valorisation via proteins and phenols. In Sustainable Governance and Management of Food Systems: Ethical Perspectives; Wageningen Academic Publishers: Wageningen, The Netherlands, 2019; pp. 74-81.

10. Andersson, I.; Backlund, A. Structure and function of Rubisco. Plant Physiol. Biochem. 2008, 46, 275-291. [CrossRef]

11. Martin, A.H.; Castellani, O.; de Jong, G.A.H.; Bovetto, L.; Schmitt, C. Comparison of the functional properties of RuBisCO protein isolate extracted from sugar beet leaves with commercial whey protein and soy protein isolates. J. Sci. Food Agric. 2019, 99, 1568-1576. [CrossRef]

12. Lamsal, B.P.; Koegel, R.G.; Gunasekaran, S. Some physicochemical and functional properties of alfalfa soluble leaf proteins. LWT_Food Sci. Technol. 2007, 40, 1520-1526. [CrossRef] 
13. Hojilla-Evangelista, M.P.; Selling, G.W.; Hatfield, R.; Digman, M. Extraction, composition, and functional properties of dried alfalfa (Medicago sativa L.) leaf protein. J. Sci. Food Agric. 2016, 97, 882-888. [CrossRef]

14. Patel, M.; Berry, J.O. Rubisco gene expression in C4 plants. J. Exp. Bot. 2008, 59, 1625-1634. [CrossRef]

15. Wang, J.; Kinsella, J.E. Composition of alfalfa leaf protein isolates. J. Food Sci. 1975, 40, 1156-1161. [CrossRef]

16. Merodio, C.; Sabater, B. Preparation and properties of a white protein fraction in high yield from sugar beet (Beta vulgaris L.) leaves. J. Sci. Food Agric. 1987, 44, 237-243. [CrossRef]

17. Knuckles, B.E.; Kohler, G.O. Functional properties of edible protein concentrates from alfalfa. J. Agric. Food Chem. 1982, 30, 748-752. [CrossRef]

18. Tamayo Tenorio, A.; Gieteling, J.; de Jong, G.A.; Boom, R.M.; van der Goot, A.J. Recovery of protein from green leaves: Overview of crucial steps for utilisation. Food Chem. 2016, 203, 402-408. [CrossRef]

19. Edwards, R.H.; Miller, R.E.; De Fremery, D.; Knuckles, B.E.; Bickoff, E.M.; Kohler, G.O. Pilot plant production of an edible white fraction leaf protein concentrate from alfalfa. J. Agric. Food Chem. 1975, 23, 620-626. [CrossRef]

20. Martin, A.H.; Nieuwland, M.; de Jong, G.A.H. Characterization of heat-set gels from RuBisCO in comparison to those from other proteins. J. Agric. Food Chem. 2014, 62, 10783-10791. [CrossRef]

21. Sheen, S.J. Comparison of chemical and functional properties of soluble leaf proteins from four plant species. J. Agric. Food Chem. 1991, 39, 681-685. [CrossRef]

22. Amer, B.; Juul, L.; Møller, A.; Møller, H.; Dalsgaard, T. Improved solubility of proteins from white and red clover-Inhibition of redox enzymes. Int. J. Food Sci. Technol. 2020, in press. [CrossRef]

23. Bray, W.J.; Humphries, C. Preparation of white leaf protein concentrate using a polyanionic flocculant. J. Sci. Food Agric. 1979, 30, 171-176. [CrossRef]

24. Fiorentini, R.; Galoppini, C. Pilot plant production of an edible alfalfa protein concentrate. J. Food Sci. 1981, 46, 1514-1517. [CrossRef]

25. Colas, D.; Doumeng, C.; Pontalier, P.; Rigal, L. Green crop fractionation by twin-screw extrusion: Influence of the screw profile on alfalfa (Medicago sativa) dehydration and protein extraction. Chem. Eng. Process. Process Intensif. 2013, 72, 1-9. [CrossRef]

26. De Fremery, D.; Miller, R.E.; Edwards, R.H.; Knuckles, B.E.; Bickoff, E.M.; Kohler, G.O. Centrifugal separation of white and green protein fractions from alfalfa juice following controlled heating. J. Agric. Food Chem. 1973, 21, 886-889. [CrossRef] [PubMed]

27. Hernández, A.; Hernández, T.; Martinez, C. Production and chemical composition of alfalfa protein concentrate obtained by freezing. Anim. Feed Sci. Technol. 1998, 72, 169-174. [CrossRef]

28. Jwanny, E.W.; Montanari, L.; Fantozzi, P. Protein production for human use from Sugarbeet: Byproducts. Bioresour. Technol. 1993, 43, 67-70. [CrossRef]

29. Kiskini, A.; Vissers, A.; Vincken, J.-P.; Gruppen, H.; Wierenga, P.A. Effect of plant age on the quantity and quality of proteins extracted from sugar beet (Beta vulgaris L.) leaves. J. Agric. Food Chem. 2016, 64, 8305-8314. [CrossRef]

30. Lamsal, B.P.; Koegel, R.G.; Boettcher, M.E. Separation of protein fractions in alfalfa juice: Effects of some pre-treatment methods. Trans. ASAE 2003, 46, 715-720. [CrossRef]

31. Merodio, C.; Martin, M.; Sabater, B. Improved separation of green and soluble leaf proteins by pH shift. J. Agric. Food Chem. 1983, 31, 957-959. [CrossRef]

32. Zhang, W.; Grimi, N.; Jaffrin, M.Y.; Ding, L. Leaf protein concentration of alfalfa juice by membrane technology. J. Membr. Sci. 2015, 489, 183-193. [CrossRef]

33. Sedlar, T.; Čakarević, J.; Tomić, J.; Popović, L. Vegetable by-products as new sources of functional proteins. Plant Foods Hum. Nutr. 2021, 76, 31-36. [CrossRef]

34. Gasteiger, E.; Hoogland, C.; Gattiker, A.; Wilkins, M.R.; Appel, R.D.; Bairoch, A. Protein identification and analysis tools on the ExPASy server. In The Proteomics Protocols Handbook; Walker, J.M., Ed.; Humana Press: Totowa, NJ, USA, 2005 ; pp. $571-607$.

35. RStudio Team. RStudio: Integrated Development for R. RStudio; RStudio, PBC: Boston, MA, USA, 2020.

36. Kuznetsova, A.; Brockhoff, P.B.; Christensen, R.H. lmerTest package: Tests in linear mixed effects models. J. Stat. Softw. 2017, 82, 1-26. [CrossRef]

37. Miller, R.E.; de Fremery, D.; Bickoff, E.M.; Kohler, G.O. Soluble protein concentrate from alfalfa by low-temperature acid precipitation. J. Agric. Food Chem. 1975, 23, 1177-1179. [CrossRef]

38. Santamaría-Fernández, M.; Ytting, N.K.; Lübeck, M. Influence of the development stage of perennial forage crops for the recovery yields of extractable proteins using lactic acid fermentation. J. Clean. Prod. 2019, 218, 1055-1064. [CrossRef]

39. Béghin, V.; Bizot, H.; Audebrand, M.; Lefebvre, J.; Libouga, D.G.; Douillard, R. Differential scanning calorimetric studies of the effects of ions and $\mathrm{pH}$ on ribulose 1, 5-bisphosphate carboxylase/oxygenase. Int. J. Biol. Macromol. 1993, 15, 195-200. [CrossRef]

40. Betschart, A.; Kinsella, J.E. Extractability and solubility of leaf protein. J. Agric. Food Chem. 1973, 21, 60-65. [CrossRef]

41. Bhatia, S.; Dahiya, R. - Concepts and Techniques of Plant Tissue Culture Science. In Modern Applications of Plant Biotechnology in Pharmaceutical Sciences; Bhatia, S., Sharma, K., Dahiya, R., Bera, T., Eds.; Academic Press: Boston, MA, USA, 2015; Chapter 4, pp. 121-156.

42. Kobbi, S.; Bougatef, A.; Balti, R.; Mickael, C.; Fertin, B.; Chaabouni, S.; Dhulster, P.; Nedjar, N. Purification and Recovery of RuBisCO Protein from Alfalfa Green Juice: Antioxidative Properties of Generated Protein Hydrolysate. Waste Biomass Valorization 2017, 8, 493-504. [CrossRef] 
43. Firdaous, L.; Fertin, B.; Khelissa, O.; Dhainaut, M.; Nedjar, N.; Chataigné, G.; Ouhoud, L.; Lutin, F.; Dhulster, P. Adsorptive removal of polyphenols from an alfalfa white proteins concentrate: Adsorbent screening, adsorption kinetics and equilibrium study. Sep. Purif. Technol. 2017, 178, 29-39. [CrossRef]

44. Tenorio, A.T.; Schreuders, F.; Zisopoulos, F.; Boom, R.; Van der Goot, A. Processing concepts for the use of green leaves as raw materials for the food industry. J. Clean. Prod. 2017, 164, 736-748. [CrossRef]

45. Muneer, F.; Hovmalm, H.P.; Svensson, S.-E.; Newson, W.R.; Johansson, E.; Prade, T. Economic viability of protein concentrate production from green biomass of intermediate crops: A pre-feasibility study. J. Clean. Prod. 2021, 294, 126304. [CrossRef]

46. Prade, T.; Muneer, F.; Berndtsson, E.; Nynäs, A.-L.; Svensson, S.-E.; Newson, W.R.; Johansson, E. Protein fractionation of broccoli (Brassica oleracea, var Italica) and kale (Brassica oleracea, var. Sabellica) leaves-A pre-feasibility assessment and evaluation of fraction phenol and fibre content. Food Bioprod. Process. 2021, in press. 